\title{
THE EFFECT OF SOCIAL, PERSONAL AND PSYCHOLOGICAL FACTORS OF STUDENTS ON THE PURCHASING DECISION OF ISLAMIC AND CONVENTIONAL BANK PRODUCTS: A CASE STUDY ON THE ISLAMIC UNIVERSITIES IN PALEMBANG
}

\author{
Andriyani Titi*, Lecturer \\ Alhadi Esya, Windarti Gusti Ayu Oka, Zahara Elvia, Senior Lecturers \\ State Polytechnic of Sriwijaya, Indonesia \\ *E-mail: titiyulian001@gmail.com
}

\begin{abstract}
This research focuses on the problem whether there any differences in the average between social, personal and psychological factors on the decisions of students of Universitas Islam Negeri (UIN) Palembang and Universitas Muhammadyah Palembang in purchasing Islamic bank products or conventional banks. The model used for this study is comparative analysis of two free samples (Independent Sample T Test), the data is processed and tested using the SPSS Version 19. The results show that the value of $t$ count on social factors is -2.304 and the significance value for social factors is 0.023 , it can be concluded that there are differences in social factors between students of UIN Palembang and Universitas Muhammadiyah Palembang in making purchasing decisions for Islamic bank products or conventional banks. The value of $t$ count on personal factors is -2.912 and the significance value for personal factors is 0.004 , it can be concluded that there are personal factor differences between students of UIN Palembang and Universitas Muhammadiyah Palembang in making purchasing decisions for Islamic bank products or conventional banks. The value of $t$ count on psychological factors is $-3,187$ and the significance value for psychological factors is 0,002 , it can be concluded that there are psychological factors differences between students of UIN Palembang and Universitas Muhammadiyah Palembang in making purchasing decisions for Islamic bank products or conventional banks. The value of $t$ count for the purchasing decision factor is $-4,538$ and the significance value for the purchasing decision factor is 0,000 , it can be concluded that there are differences in purchasing decision factors between students of UIN Palembang and Universitas Muhammadiyah Palembang in making purchasing decisions for Islamic bank products or conventional banks.
\end{abstract}

\section{KEY WORDS}

Social, personal, psycological, purchasing decision, Islamic bank, conventional bank.

Consumer behavior is a process carried out by someone or an organization in finding, buying, using, evaluating and and other actions in order to meet their needs. Consumer behavior before consuming a product / service will go through several stages, namely the stage before purchase, purchase, and after purchase.According to The American Marketing Association as cittedin Setiadi (2015: 2), consumer behavior is "a dynamic interaction between affection and cognition, behavior and environment where people carry out exchange activities in their lives".Schiffman and Kanuk in Sumarwan, et al., (2012: 186), define consumer behavior as "consumer behavior as an action directly involved in obtaining, consuming and consuming products or services, including the process of decisions that precede and follow this action".

Based on the opinions of some experts such as Schiffman and Kanuk, Kotler and others study about the factors that influence consumer behavior. According to them, broadly there are two factors that influence consumer behavior, namely internal factors and external factors. Internal factors consist of: (a) Learning and memory experience (learning and memory); (b) Personality and self-concept (personality and self-concept); (c) Motivation and involvement (motivation and involvement); (d) Attitude (attitude); (e) Perception. External 
factors consist of: (a) Cultural factors; (b) Social factors; (c) Economic factors; (d) Marketing mix factors.

In addition to internal and external factors, there are two more factors that usually affect consumer behavior, namely 1 . Socio-cultural factors with the following indicators: (a) cultural factors; (b) Social class factors; (c) role model factors; (d) Family factors. 2. Psychological factors with the indicators of: (a) learning experience factors; (b) personality factors; (c) attitude and belief factors; and (d) self-concept or self-concept.

In 2008 a new trend emerged for the formation of Islamic banks through the mechanism of acquisition and conversion from conventional banks. This trend emerged after the enactment of Law number 21 of 2008 concerning Islamic banking. The establishment of Islamic banks in Indonesia certainly requires research concerning consumer behavior in addressing this trend because based on the facts in the field, one of the obstacles faced by Islamic banking is the lack of socialization to the public about the existence of Islamic banks. Socialization is not only about introducing the existence of Islamic banks somewhere, but also introducing mechanisms, Islamic bank products and Islamic bank financial instrument instruments to the public.

Most people already know about the existence of Islamic banks, but they still experience the lack of information on products offered by Islamic banks and the assumption that the supporting facilities provided by Islamic banks are still inferior to the facilities offered by conventional banks. Theories about internal and external factors of consumer behavior which consist of social, personal and psychological factors can be used to provide understanding and knowledge to the public about Islamic banks and can also be used to influence people's views about Islamic banks themselves.

According to Antonio as cited in Hidayati (2017: 32), sharia bank is "an operational bank and its products are developed based on the principles of Islamic syariah namely AlQur'an and Al-Hadist". Sharia banks are banks that run their operations in accordance with the Islamic sharia provisions, especially in relation to Islamic modalities. The practices of doing things away from practices that are concerned with the elements of usury.

Based on Law No. 10 of 1998 Article 1 paragraph 13, sharia principles are rules of agreement based on Islamic law between banks and other parties for depositing funds and or financing business activities, or other activities declared in accordance with sharia, including financing based on the profit sharing principle (mudharabah), financing based on the principle of equity participation (musyarakah), the principle of buying and selling goods by obtaining profits (murabahah), or financing capital goods based on the principle of pure rent without choice (ijarah) (Hidayati, 2017: 32). Hidayati (2017: 30) mentions that to see the development of banking in Indonesia, there are currently 2,652 banks built (outside BRI and BRI's Village Unit). According to the American standard, it is derived from the population of Indonesia, so this country still needs 7,800 banks. The banking sector plays a significant role in the Indonesian economy.

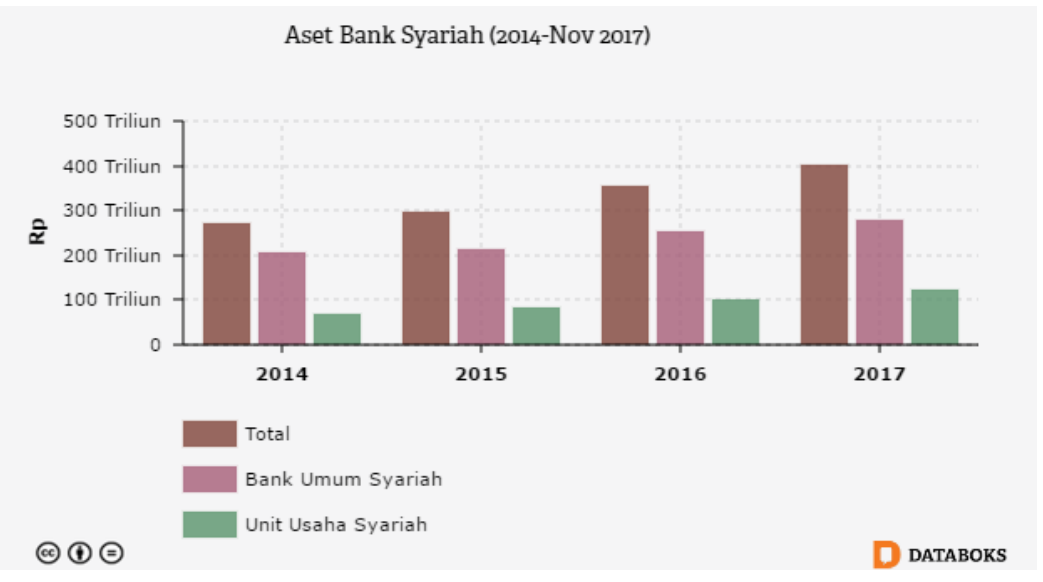

Figure 1 - Assets of Islamic Bank in 2017 (Source: OJK, Financial Services Authority, 2017) 
Islamic banking in Indonesia has experienced growth in terms of institutions. According to the Financial Services Authority report, up to July 2016 there were 12 Sharia Commercial Banks (BUS), 22 Sharia Business Units (UUS), and 103 Sharia People's Financing Banks (BPRS) spread throughout almost all regions of Indonesia. Based on data from the Indonesian Banking Statistics of the Financial Services Authority, Islamic commercial bank assets up to the end of June 2017 has reached Rp 271.3 trillion, which means it grew 6.74 percent compared to December 2016. This figure is also increased 26 percent from the position in June 2016.

The Bank with the Biggest Asset in Indonesia is PT Bank Mandiri (Persero) Tbk and PT Bank Rakyat Indonesia (Persero) Tbk still leads the bank with the largest assets in the country. The two State-Owned Enterprises (BUMN) have assets in excess of Rp. 1,000 trillion. While PT Bank Central Asia Tbk, which is a private bank with the largest assets, is third. The plan to merge PT Bank Tabungan Pensiun National Tbk (BTPN) and PT Bank Sumitomo Mitsui Indonesia (BSMI) will make the bank categorized under 10 banks with the largest assets in the country. Based on published financial reports as of September 2017, BTPN's assets amounted to Rp. 93.8 trillion and BSMI reached Rp. 68.7 trillion. So if the assets of the two banks are combined it will reach Rp 162.5 trillion. With such assets, the results of the merger of the two banks will shift the position of PT Bank Permata Tbk, which is currently in tenth place with assets of IDR 150.7 trillion.

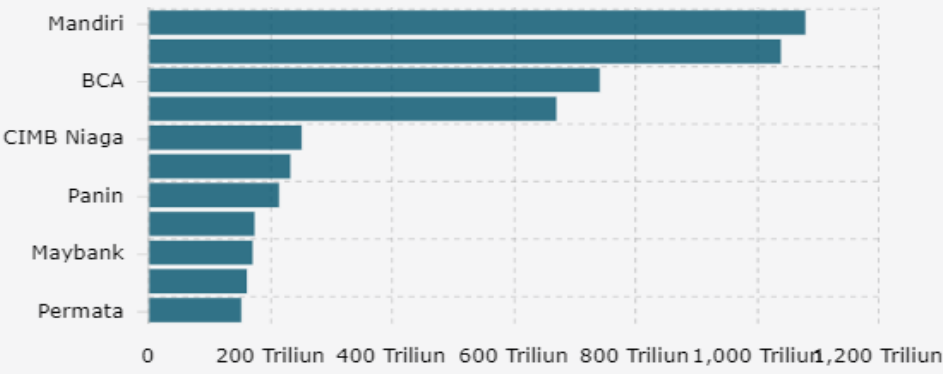

Figure 2 - The Asset of 10 Biggest Banks in Indonesia in 2017 (Source: OJK, Financial Services Authority, 2017)

The State Islamic University (UIN) and Muhammadyah University are two Islamic Universities located in Palembang City. These two campuses certainly learn about the laws in Islam which regulate transactions using Islamic banks and conventional banks, especially laws governing bank interest. Reality in the field shows that not all students from this campus use Islamic banks as a place for them to conduct financial transactions, even some of the universities from these universities do not use them. The Muhammadiyah University of Palembang collaborated with the Bank of South Sumatra Babel in conducting its financial transactions; the UIN Palembang used Bank BRI, South Sumatra Babel and Bank Mandiri Syariah.

To find out and prove whether "there are differences in the average between social, personal and psychological factors on the decisions of students of the State Islamic University (UIN) Palembang and the Muhammadiyah University of Palembang in purchasing Islamic bank products or conventional banks" this study was prepared with the title of "The Influence of Social, Personal and Psychological Factors Students onPurchasing Decision of Islamic Banks or Conventional Banks (Case Study of Two Islamic Universities in the City of Palembang)".

\section{METHODS OF RESEARCH}

The problem examined in this study is based on the fact that consumer behavior, especially regarding social, personal and psychological factors play an important role for students in purchasing Islamic or conventional bank products. Based on the three factors 
mentioned above, the problem can be formulated as follows: "Are there any differences in the average between social, personal and psychological factors on the decisions of students of Universitas Islam Negeri (UIN) Palembang and Universitas Muhammadyah Palembang in purchasing Islamic bank products or conventional banks".

This research will be conducted at two Islamic Universities in Palembang, namely: Universitas Islam Negeri (UIN) Palembang with the address JI. Prof. K.H. Zainal Abidin Fikri KM. 3.5, Pahlawan, Kemuning, Palembang City, South Sumatra 30126 and Universitas Muhammadyah Palembang with the address JI. General A. Yani, 13 Ulu, SeberangUlu II, Palembang City, South Sumatra 30116 . The study population is students in two Islamic colleges that are active and registered in 2018 (see table 1).

Table 1 - Study Population

\begin{tabular}{|l|l|l|}
\hline No. & University & Number of Students \\
\hline 1. & Universitas Islam Negeri (UIN) Palembang & 16.539 \\
\hline 2. & UniversitasMuhammadyah Palembang & 11.840 \\
\hline Total & 28.379 \\
\hline
\end{tabular}

Source: Researach and Development of Ministry of Research, Technology and Higher Education (Diktilitbang), 2018.

Not all populations of students can be sampled, therefore for this research to represent the population, Slovin formula is used (Umar, 2001), the total sample is 100 people. Because the number of sub-populations is not the same between each University, the determination of the number of samples for each sub-population uses Proportional Random Sampling procedures (Sanusi, 2003), by taking samples randomly with a proportional number for each department (see table 2).

Table 2 - Study Sample

\begin{tabular}{|c|c|c|c|c|}
\hline No. & University & $\begin{array}{c}\text { Number of } \\
\text { Students }\end{array}$ & $\begin{array}{c}\text { Calculation } \\
(\mathrm{Ni} / \mathrm{Ni} \times \mathrm{n})\end{array}$ & $\begin{array}{c}\text { Sample } \\
\text { (students) }\end{array}$ \\
\hline 1. & $\begin{array}{c}\text { Universitas Islam Negeri (UIN) } \\
\text { Palembang }\end{array}$ & 16.539 & $N i=\frac{16.539}{28.379} \times 100$ & $58,27=58$ \\
\hline 2. & Universitas Muhammadyah Palembang & 11.840 & $N i=\frac{11.840}{28.379} \times 100$ & $41,7=42$ \\
\hline \multicolumn{2}{|c|}{ Total } & & & 100 \\
\hline
\end{tabular}

Source: Researach and Development of Ministry of Research, Technology and Higher Education (Diktilitbang), 2018.

The easurement of variable scores on question items in this study is using a Likert scale. Alternative assessments in measuring these items consist of 5 (five) alternative choices that have very low to very high levels (worth $1 \mathrm{dd}$. 5) that are applied vary according to the question. Thus measurements can be achieved which not only describe the categories or sequences that are inorginal scales but alsoin interval scale. The statistical analysis model used is using the Sample T Test (Independent Test method). Independet Sample T Test is a T sample test that is not related / free, indicating that there is no relationship between the two samples that will be tested.

Data analysis used in this study is by collecting data, which is then processed using quantitative analysis and qualitative analysis.

\section{RESULTS AND DISCUSSION}

Data obtained from questionnaires distributed to both university students were then inputted and processed through the SPSS program. In this section we will discuss the profile of respondents. To analyze the profile of respondents, frequency tables are used to see the composition of respondents' answers on each variable. Profile analysis of respondents regarding both universities is as follows: 
Table 3 - Descriptics Statistics

\begin{tabular}{|c|c|c|c|}
\hline \multicolumn{2}{|r|}{$n / n$} & Age & Gender \\
\hline \multirow{2}{*}{$\mathrm{N}$} & Valid & 100 & 100 \\
\hline & Missing & 0 & 0 \\
\hline \multicolumn{2}{|r|}{ Mean } & 19.70 & 1.63 \\
\hline \multicolumn{2}{|r|}{ Std. Error of Mean } & .116 & .049 \\
\hline & 20.00 & 2.00 \\
\hline \multirow{2}{*}{\multicolumn{2}{|c|}{$\begin{array}{c}\text { Mode } \\
\text { Std. Deviation }\end{array}$}} & 20 & 2 \\
\hline & & 1.159 & .485 \\
\hline \multicolumn{2}{|r|}{ Variance } & 1.343 & .235 \\
\hline \multicolumn{2}{|r|}{ Skewness } & .254 & -.547 \\
\hline \multicolumn{2}{|r|}{ Std. Error of Skewness } & .241 & .241 \\
\hline \multicolumn{2}{|r|}{ Kurtosis } & 1.375 & -1.736 \\
\hline \multicolumn{2}{|r|}{ Std. Error of Kurtosis } & .478 & .478 \\
\hline \multicolumn{2}{|r|}{ Range } & 6 & 1 \\
\hline \multicolumn{2}{|r|}{ Minimum } & 17 & 1 \\
\hline \multicolumn{2}{|r|}{ Maximum } & 23 & 2 \\
\hline \multicolumn{2}{|r|}{ Sum } & 1970 & 163 \\
\hline
\end{tabular}

Table 4 - Frequency of Respondents Age

\begin{tabular}{|c|c|c|c|c|c|}
\hline \multicolumn{2}{|c|}{$\mathrm{n} / \mathrm{n}$} & Frequency & Percent & Valid Percent & Cumulative Percent \\
\hline \multirow{6}{*}{ Valid } & 17 & 4 & 4.0 & 4.0 & 4.0 \\
\cline { 2 - 6 } & 18 & 8 & 8.0 & 8.0 & 12.0 \\
\cline { 2 - 6 } & 19 & 26 & 26.0 & 26.0 & 38.0 \\
\cline { 2 - 6 } & 20 & 47 & 47.0 & 47.0 & 85.0 \\
\cline { 2 - 6 } & 21 & 9 & 9.0 & 9.0 & 94.0 \\
\cline { 2 - 6 } & 22 & 3 & 3.0 & 3.0 & 97.0 \\
\cline { 2 - 6 } & 23 & 3 & 100.0 & 100.0 & 100.0 \\
\cline { 2 - 6 } & Total & 100 & 100.0 & \\
\hline
\end{tabular}

In table 4 above, it can be seen that the lowest age of respondents is 17 years old (4 people) and the highest age of respondents is 23 years old ( 3 people).

Table 5 - Gender

\begin{tabular}{|c|c|c|c|c|c|}
\hline \multicolumn{2}{|c|}{$\mathrm{n} / \mathrm{n}$} & Frequency & Percent & Valid Percent & Cumulative Percent \\
\hline \multirow{3}{*}{ Valid } & Male & 37 & 37.0 & 37.0 & 37.0 \\
\cline { 2 - 6 } & Female & 63 & 63.0 & 63.0 & 100.0 \\
\cline { 2 - 6 } & Total & 100 & 100.0 & 100.0 & \\
\hline
\end{tabular}

It can be seen that in Table 5, the number of respondents who are male are 37 people and female are 63 people.

The Independent Sample T Test is used to test the comparison of two independent sample group averages. This study examines whether there are differences in the value of social factors, personal factors, and psychological factors on purchasing decisions between students of UIN Palembang and Universitas Muhammadiyah Palembang. The following are the results of the calculation:

Table 6 - Group Statistics

\begin{tabular}{|c|c|c|c|c|c|}
\hline & University & $\mathrm{N}$ & Mean & Std. Deviation & Std. Error Mean \\
\hline \multirow{2}{*}{ Social Factor } & 1 & 58 & 19.76 & 2.473 & .325 \\
\cline { 2 - 6 } & 2 & 42 & 21.02 & 3.008 & .464 \\
\hline \multirow{2}{*}{ Personal Factor } & 1 & 58 & 23.71 & 3.608 & .474 \\
\cline { 2 - 6 } & 2 & 42 & 25.71 & 3.094 & .477 \\
\hline \multirow{2}{*}{ Psycholofical Factor } & 1 & 58 & 15.52 & 2.326 & .305 \\
\cline { 2 - 6 } & 2 & 42 & 17.05 & 2.429 & .375 \\
\hline \multirow{2}{*}{ Purchasing Decision } & 1 & 58 & 19.78 & 2.847 & .374 \\
\cline { 2 - 5 } & 2 & 42 & 22.07 & 1.905 & .294 \\
\hline
\end{tabular}

Universitas Islam Negeri (UIN) =1, Universitas Muhammadyah $=2$. 
Tabel 7 - Independent Samples Test

\begin{tabular}{|c|c|c|c|c|c|c|c|c|c|c|}
\hline & \multicolumn{2}{|c|}{$\begin{array}{l}\text { Levene's Test } \\
\text { for Equality of } \\
\text { Variances }\end{array}$} & \multicolumn{7}{|c|}{ t-test for Equality of Means } \\
\hline & & \multirow[t]{2}{*}{$\mathrm{F}$} & \multirow[t]{2}{*}{ Sig. } & \multirow[t]{2}{*}{$\mathrm{T}$} & \multirow[t]{2}{*}{ Df } & \multirow{2}{*}{$\begin{array}{l}\text { Sig. } \\
(2- \\
\text { tailed })\end{array}$} & \multirow[t]{2}{*}{$\begin{array}{c}\text { Mean } \\
\text { Difference }\end{array}$} & \multirow[t]{2}{*}{$\begin{array}{l}\text { Std. Error } \\
\text { Difference }\end{array}$} & \multicolumn{2}{|c|}{$\begin{array}{l}95 \% \text { Confidence } \\
\text { Interval of the } \\
\text { Difference }\end{array}$} \\
\hline & & & & & & & & & Lower & Upper \\
\hline \multirow[b]{2}{*}{ Social Factor } & $\begin{array}{c}\text { Equal } \\
\text { variances } \\
\text { assumed }\end{array}$ & 1.382 & 243 & -2.304 & 98 & .023 & -1.265 & .549 & -2.355 & -.176 \\
\hline & $\begin{array}{c}\text { Equal } \\
\text { variances } \\
\text { not } \\
\text { assumed }\end{array}$ & & & -2.233 & 77.589 & .028 & -1.265 & .566 & -2.393 & -.137 \\
\hline \multirow[b]{2}{*}{$\begin{array}{l}\text { Personal } \\
\text { Factor }\end{array}$} & $\begin{array}{c}\text { Equal } \\
\text { variances } \\
\text { assumed }\end{array}$ & 2.037 & .157 & -2.912 & 98 & .004 & -2.007 & .689 & -3.375 & -.639 \\
\hline & $\begin{array}{c}\text { Equal } \\
\text { variances } \\
\text { not } \\
\text { assumed }\end{array}$ & & & -2.984 & 95.140 & .004 & -2.007 & .673 & -3.343 & -.672 \\
\hline \multirow[b]{2}{*}{$\begin{array}{l}\text { Psychological } \\
\text { Factor }\end{array}$} & $\begin{array}{c}\text { Equal } \\
\text { variances } \\
\text { assumed }\end{array}$ & .019 & .890 & -3.187 & 98 & .002 & -1.530 & .480 & -2.483 & -.578 \\
\hline & $\begin{array}{c}\text { Equal } \\
\text { variances } \\
\text { not } \\
\text { assumed }\end{array}$ & & & -3.165 & 86.200 & .002 & -1.530 & .484 & -2.492 & -.569 \\
\hline \multirow{2}{*}{$\begin{array}{l}\text { Purchasing } \\
\text { Decision }\end{array}$} & $\begin{array}{c}\text { Equal } \\
\text { variances } \\
\text { assumed }\end{array}$ & 4.187 & .043 & -4.538 & 98 & .000 & -2.296 & .506 & -3.299 & -1.292 \\
\hline & $\begin{array}{c}\text { Equal } \\
\text { variances } \\
\text { not } \\
\text { assumed }\end{array}$ & & & -4.827 & 97.471 & .000 & -2.296 & .476 & -3.239 & -1.352 \\
\hline
\end{tabular}

Table 7 explains the Levene's (homogeneity test) and Independent Samples test results that are used to find out about differences in social, personal, psychological and purchasing decisions between the students of both universities. Leven's test is done to find out the type of data variant (same or different). If the same, then the test Equal variances assumed will be used but if it is different, then equal variances not assumed will be used.

The Levene's test results can be seen in the $F$ value and significance. In table 7 above, it is known that the $F$ value for social factor variables is 1.382 with a significance of 0.243 , because the significance is greater than 0.05 , it can be concluded that the data variant for social factors is the same. The $F$ value for personal factor variables is 2.037 with a significance of 0.157 , because the significance is greater than 0.05 , it can be concluded that the data variant for personal factors is the same. The value of $F$ for psychological factor variables is 0.019 with a significance of 0.890 , because the significance is greater than 0.05 , it can be concluded that the data variant for psychological factors is the same. The value of $F$ for the purchase decision variable is 4.187 with a significance of 0.043 , because the significance is smaller than 0.05 , it can be concluded that the data variant for the purchase decision variable is not the same (different).

For decision making on the Independent Samples $T$ test, it is determined by looking at the $t$-value and the significance of equal assume. If the significance is less than 0.05 then the conclusion is there are differences in values between social factors, personal factors, psychological factors and purchasing decisions between the students of the two universities. Based on the hypothesis, $\mathrm{Ho}=$ there is no difference between the average value of students inUIN Palembang and Universitas Muhammadiyah Palembang on social factors, personal factors and psychological factors in purchasing decision of Islamic or conventional bank products. Furthermore, $\mathrm{Ha}=$ there is a difference between the average value of students inUIN Palembang and Universitas Muhammadiyah Palembang on social factors, personal factors and psychological factors in purchasing decision of Islamic or conventional bank 
products. Test criteria are if - $t$ table $\leq t$ count $\leq t$ table, then Ho is accepted and if $-t$ counts $<-t$ table or $t$ count $>t$ table, then Ho is rejected.

From table 7 above it is known for social factors the value of -t count <-t table $(-2.304$ $<-1,984)$, then Ho is rejected, so it can be concluded that "there is social factors difference between the average value of students inUIN Palembang and Universitas Muhammadiyah Palembang in purchasing decision of Islamic or conventional bank products. As for the significance, if the significance is $>0.05$, then $\mathrm{Ho}$ is accepted, and if the significance is $<0.05$, then $\mathrm{Ho}$ is rejected. The significance value for social factors is 0.023 , then Ho is rejected. Therefore, it can be concluded that there is social factors difference between students in UIN Palembang and Universitas Muhammadiyah Palembang in purchasing decision of Islamic or conventional bank products.

For personal factors the value of -t count $<-t$ table $(-2.912<-1,984)$, then Ho is rejected, so it can be concluded that there is personal factors difference between the average value of students in UIN Palembang and Universitas Muhammadiyah Palembang in purchasing decision of Islamic or conventional bank products. For the test results based on the significance value, for personal factors is 0.004 , then $\mathrm{Ho}$ is rejected. Thus it can be concluded that there is a difference in the average between students of UIN Palembang and Universitas Muhammadiyah Palembang in making purchasing decisions for syariah bank products or conventional banks.

For pyscholofical factors, the valueof-tcount $<-t$ table $(-3,187<-1,984)$, therefore Ho is rejected and it can be concluded that there is psychological factors difference between the average value of students inUIN Palembang and Universitas Muhammadiyah Palembang in purchasing decision of Islamic or conventional bank products. For the test results based on the significance value, for personal factors is 0.002 , then Ho is rejected. Thus it can be concluded that there is a difference in the average between students of UIN Palembang and Universitas Muhammadiyah Palembang in making purchasing decisions for syariah bank products or conventional banks.

For purchasing decision the valueof-tcount $<-t$ table $(-4,538<-1,984)$, thus Ho is rejected and it can be concluded that there is purchasing decision factors difference between the average value of students in UIN Palembang and Universitas Muhammadiyah Palembang in purchasing decision of Islamic or conventional bank products. For the test results based on the significance value, for personal factors is 0.000 , then Ho is rejected. Thus it can be concluded that there is a difference in the average between students of UIN Palembang and Universitas Muhammadiyah Palembang in making purchasing decisions for syariah bank products or conventional banks.

Individual actions in making decisions to obtain, use, determine products and services are called consumer behavior. Broadly speaking there are two factors that influence consumer behavior, namely internal factors and external factors. In influencing consumer decisions to choose to save in Islamic banks or conventional banks, banks must pay attention to internal and external factors of consumer behavior. For Islamic banks, one of the obstacles faced by Islamic banking is the lack of socialization to the public about the existence of Islamic banks. Socialization is not only about introducing the existence of Islamic banks, but also introducing mechanisms, products and instruments to the public. Most people already know about the existence of Islamic banks, but they lack information about products offered by Islamic banks and the assumption that the supporting facilities provided by Islamic banks are still inferior to the facilities offered by conventional banks. Theories about internal and external factors of consumer behavior which consist of social, personal and psychological factors can be used to provide understanding and knowledge to the public about Islamic banks and can also be used to influence people's views about Islamic banks themselves.

\section{CONCLUSION AND SUGGESTIONS}

The value of $t$ count on social factors is -2.304 and the significance value for social factors is 0.023 , it can be concluded that there are differences in social factors between 
students of UIN Palembang and Universitas Muhammadiyah Palembang in making purchasing decisions for Islamic bank products or conventional banks. The value of $t$ count on personal factors is -2.912 and the significance value for personal factors is 0.004 , it can be concluded that there are personal factor differences between students of UIN Palembang and Universitas Muhammadiyah Palembang in making purchasing decisions for Islamic bank products or conventional banks. The value of t count on psychological factors is $-3,187$ and the significance value for psychological factors is 0,002 , it can be concluded that there are psychological factors differences between students of UIN Palembang and Universitas Muhammadiyah Palembang in making purchasing decisions for Islamic bank products or conventional banks. The value of $t$ count for the purchasing decision factor is $-4,538$ and the significance value for the purchasing decision factor is 0,000 , it can be concluded that there are differences in purchasing decision factors between students of UIN Palembang and Universitas Muhammadiyah Palembang in making purchasing decisions for Islamic bank products or conventional banks.

Islamic banks must socialize to the public about the existence of Islamic banks such as introducing the existence of Islamic banks, mechanism or procedure for saving in Islamic banks, its products and instruments. Islamic banks can use the theory of consumer behavior concerning internal and external factors to attract people to save in Islamic banks. This theory is used to provide understanding and knowledge to the public about Islamic banks and can also be used to influence people's views about Islamic banks themselves.

\section{REFERENCES}

1. Alwi, Syafaruddin. 2001. Manajemen Sumber Daya Manusia (Human Resource Management). Yograkarta: BPFE-Yograkarta.

2. Adawiyah, Wiwiek Rabiatul (2010). Pertimbangan, Pengetahuan, and Sikap Konsumen Individu Terhadap Bank Syariah (Considerations, Knowledge, and Attitudes of Individual Consumers towards Islamic Banks). Jurnal Ekonomi Pembangunan Volume 11, Nomor 2, Desember 2010, hal. 191-201, Jakarta: Fakultas Ekonomi Universitas Jenderal Soedirman.

3. Arsy, R.M.A. 2012. Pengaruh Faktor budaya, Sosial, Pribadi and Psikologis Konsumen Terhadap Keputusan Pembelian Motor Matic Yamaha (Study kasuspada PT Tunas Kencana Deta Bekasi) (Influence of Cultural, Social, Psychological and Psychological Factors on the Decision of Purchasing Motor Matic Yamaha (Case Study at PT Tunas Kencana Deta Bekasi). Jakarta: Jurusan Manajemen, Fakultas Ekonomi, Universitas Gunadarma. Skripsi. Tidak dipublikasikan.

4. Antonio, M. Syafi'l dkk., 2006. Bank Syariah "Analisis Kekuatan, Kelemahan, Peluang, and Ancaman" (Syariah Bank "The Analysis of Strength, Weakness, Opportunity, and Threats").Yogyakarta :Ekonisia

5. Dikti, Riset. 2018. Pangkalan Data Pendidikan Tinggi Kementerian Riset, Teknologi and Pendidikan Tinggi. https://forlap.ristekdikti.go.id/mahasiswa/homerekap (diakses tanggal 1 Februari 2018).

6. Firdaus, Muhammad N.H., dkk, 2005. Konsep \& Implentasi Bank Syariah (Concept and The Implementation of Islamic Bank). Jakarta: Renaisan

7. Hidayati, Nadiah, dkk., 2017. Determinant Of Efficiency Of The Islamic Banking In Indonesia. Buletin Ekonomi Moneter and Perbankan, Volume 20, Nomor 1, Juli 20172016. Jakarta: Bank Indonesia.

8. Ismail. 2010. Perbankan Syariah (Islamic Banking), Jakarta: Kencana Prenada Media Group.

9. Irsyad, Husain Muhammad. 2015. Analisis Faktor-faktor yang Mempengaruhi Keputusan Mahasiswa FIAI UII dalam Memilih Layanan Bank (Syariah) (Analysis of Factors Affecting the Decision of FIAI UII Students in Choosing Bank Services (Sharia)). Yogyakarta: Fakultas IImu Agama Islam Universitas Islam Indonesia KampusPusat. Skripsi yang dipublikasi. 
10. Kreitner, Robert and Kinicki, Angelo. 2005. Perilaku Organisasi (Organizational Behaviour). Alih Bahasa Erly Sudandy. Buku 1. Edisi 5. Jakarta: SalembaEmpat.

11. Malthis, Robert L, dkk., 2002. Manajemen Sumber Daya Manusia (Human Resource Management). Jakarta: SalembaEmpat.

12. Muhammad. 2005. Manajemen Bank Syariah (Islamic Banking Mangement). Yogyakarta: UPP AMP YKPN.

13. Maski, Ghozali. 2010. Analisis Keputusan Nasabah Menabung: Pendekatan Komponendan Model Logistik Studi Pada Bank Syariah di Malang (Analysis of Customer Savings Decisions: Component Approach and Study Logistics Model in Islamic Banks in Malang). Journal of Indonesian Applied Economics Vol. 4 No. 1 Mei 2010, 43-57: Fakultas Ekonomi Universitas Brawijaya.

14. Peter, Paul, J. and Jerry C. Olson. 2000. Consumer Behavior, Perilaku Konsumen and . Jakarta: Erlangga.

15. Robin, Stephen P., 2003. Perilaku Organisasi (Organizational Behaviour). Alih Bahasa Drs. Benyamin Molan. Edisi ke-10. Jakarta: Gramedia.

16. Priyatno, Duwi. 2012. Belajar Cepat Olah Data Statistik Dengan SPSS (Learn Quickly with SPSS Statistical Data). Yogyakarta: CV Andi Offset.

17. Rivai, Harif Amali, dkk, 2017. Identifikasi Faktor Penentu Keputusan Konsumen Dalam memilih Jasa Perbankan: Bank Syariah VS Bank Konvensional. (Identification of Consumer Decision Factors in Selecting Banking Services: Islamic Banks VS Conventional Banks). http://www.bi.go.id/id/publikasi/perbankan-danstabilitas/arsitektur/Documents/be97b7ef957a461a90ec56f3a78022b3 Identifikasi Faktor Penentu Keputusan Konsumen Dalam Mem.pdf (diakses tanggal 1 Februari 2018).

18. Schiffman, Leon and Leslie Lazar Kanuk. 2008. Perilaku Konsumen (Consumer Behaviour). Edisi ke-7. Jakarta: PT Indeks

19. Sumarwan, Ujang. 2011. Perilaku Konsumen: Teori and Penerapannya dalam Pemasaran (Consumer Behavior: Theory and Its Application in Marketing). Jakarta: Penerbit PT Ghalia Indonesia

20. Sudarsono, Heri. 2008. Bank and Lembaga Keuangan Syariah Deskripsi and Ilustrasi (Sharia Banks and Financial Institutions Descriptions and Illustrations).Yogyakarta: Ekonesia.

21. Syafril danNuril Huda. 2015. Analisis Faktor Sosial, Budaya and Psikologis yang Mempengaruhi Keputusan Nasabah Memilih Pembiayaan PadaWarung Mikro (Studi Pada PT Bank Syariah Mandiri Cabang Banjarmasin) (Analysis of Social, Cultural and Psychological Factors Affecting Customer Decisions Choosing Financing at Warung Micro (Study at PT Bank Syariah Mandiri Banjarmasin Branch). http://jwm.ulm.ac.id/id/index.php/jwm/article/viewFile/6/6. Diaksestanggal 7 Februari 2018.

22. Umar. Azwarlskandar. 2017. Index of Syariah Financial Inclusion in Indonesia. Buletin Ekonomi Moneter and Perbankan, Volume 20, Nomor 1, Juli 2017. 